\title{
Article
}

\section{Fiber-optic immunosensor for detection of Crimean- Congo Hemorrhagic fever IgG antibodies in patients}

Firoz Algaar, Evgeni Eltzov, Marina M. Vdovenko, Ivan Yurievich Sakharov, Luka Fajs, Manfred Weidmann, Ali Mirazimi, and Robert S. Marks

Anal. Chem., Just Accepted Manuscript • DOI: 10.1021/acs.analchem.5b01728 • Publication Date (Web): 07 Jul 2015

Downloaded from http://pubs.acs.org on July 14, 2015

\section{Just Accepted}

"Just Accepted" manuscripts have been peer-reviewed and accepted for publication. They are posted online prior to technical editing, formatting for publication and author proofing. The American Chemical Society provides "Just Accepted" as a free service to the research community to expedite the dissemination of scientific material as soon as possible after acceptance. "Just Accepted" manuscripts appear in full in PDF format accompanied by an HTML abstract. "Just Accepted" manuscripts have been fully peer reviewed, but should not be considered the official version of record. They are accessible to all readers and citable by the Digital Object Identifier (DOI®). "Just Accepted" is an optional service offered to authors. Therefore, the "Just Accepted" Web site may not include all articles that will be published in the journal. After a manuscript is technically edited and formatted, it will be removed from the "Just Accepted" Web site and published as an ASAP article. Note that technical editing may introduce minor changes to the manuscript text and/or graphics which could affect content, and all legal disclaimers and ethical guidelines that apply to the journal pertain. ACS cannot be held responsible for errors or consequences arising from the use of information contained in these "Just Accepted" manuscripts. 
Fiber-optic immunosensor for detection of Crimean-Congo Hemorrhagic fever IgG antibodies in patients

\author{
Firoz Algaar. ${ }^{a}$, Evgeni Eltzov ${ }^{b, c}$, Marina M. Vdovenko ${ }^{d}$, Ivan Yu. Sakharov ${ }^{d}$, Luka Fajs ${ }^{c}$, \\ Manfred Weidmann ${ }^{e}$, Ali Mirazimi ${ }^{\mathrm{f} g, \mathrm{~h}, \mathrm{j}}$, and Robert S. Marks ${ }^{\mathrm{a}, \mathrm{b}, \mathrm{c}, \mathrm{k}, \mathrm{m}}{ }^{*}$ \\ a Department of Environmental Engineering, Ben-Gurion University of the Negev, Beer- \\ Sheva 84105, Israel \\ ${ }^{b}$ Department of Biotechnology Engineering, Ben-Gurion University of the Negev, Beer- \\ Sheva 84105, Israel \\ ' School of Material Science and Engineering, Nanyang Technology University, Nanyang \\ Avenue, 639798, Singapore \\ d Department of Chemistry, Lomonosov Moscow State University, 119991 Moscow, \\ Russia \\ e Institute of Aquaculture, University of Stirling, Stirling, United Kingdom \\ ${ }^{f}$ Public Health Agency of Sweden, Stockholm, Sweden \\ ${ }^{g}$ Karolinska Institute, Stockholm, Sweden \\ h Institute for Clinical and Experimental Medicine, Linköping University, Linköping, \\ Sweden \\ ${ }^{j}$ National Veterinary Institute, Uppsala, Sweden \\ ${ }^{k}$ National Institute of Biotechnology in the Negev, Ben-Gurion University of the Negev, \\ Beer-Sheva, Israel \\ $\mathrm{m}$ The Ilse Katz Center for Meso and Nanoscale Science and Technology, Ben-Gurion \\ University of the Negev, Beer-Sheva, Israel \\ * Corresponding author \\ e-mail: rsmarks@bgu.ac.il \\ Tel: +972-8-6477182
}




\section{Abstract}

Crimean-Congo hemorrhagic fever (CCHF) is a severe viral disease with high fatality rate. CCHF virus is endemic in parts of Africa, Asia, Middle East and southeastern Europe. Rapid diagnostics of CCHF is vital for appropriate clinical management and prevention of secondary spread from human-to-human. Currently, diagnostics relies on Real-Time RTPCR and antibody or antigen detection using ELISA. These methods require trained personnel and expensive equipment and are not appropriate for point-of-care (POC) diagnostics. Furthermore there are no POC assays available for CCHF.

We developed a fiber-optic biosensor for the detection of CCHF IgG antibodies. In order to improve sensitivity, we optimized both the bioreceptor immobilization protocol and the chemiluminescence substrate formulation. The resulting protocol showed a 100 -fold greater sensitivity for detection of CCHF antibodies. Finally, we evaluated the fiber-optic biosensor with two CCHF patient sera. We showed that the fiber-optic biosensor is 10times more sensitive that colorimetric ELISA and is able to detect both patients with high and low levels of IgG antibodies. We believe that the fiber-optic biosensor is a suitable alternative to ELISA as it is much more sensitive and makes it possible to detect small amount of antibodies at an early stage of infection, and can be integrated as a point-of-care diagnostic system of CCHF.

\section{Introduction}

Crimean-Congo hemorrhagic fever (CCHF) is a severe viral disease with an average case fatality rate of $5-30 \%$. CCHF virus is the most widespread tick-borne virus in the world, with cases reported from Africa, Middle East, Asia, Russia and southeastern Europe. The virus is transmitted to humans mainly by infected ticks from the genus Hyalomma or by contact with blood or tissues from infected humans and animals. CCHF virus is classified as a BSL-4 agent due to its high pathogenicity, possibility of spread from human to human and because there is no effective treatment or vaccine available [1]. Rapid diagnostics are essential for effective infection control and prevention of spread of the disease from human to human. Namely, healthcare professionals are at high risk of 
infection due to their close contact with patients especially during invasive and aerosolforming interventions and many nosocomial transmissions have been reported ${ }^{1}$.

Quick diagnostics provide the basis for the implementation of proper infection control measures and patient management ${ }^{2-4}$. Currently the diagnostics of acute CCHF relies mainly on the detection of viral RNA with Real-Time RT-PCR. This method enables quick, sensitive and specific detection, but is not suitable for point of care (POC) diagnostics, as it requires trained personnel and expensive equipment ${ }^{5,6}$. Besides, these criteria are mostly not met in rural areas where CCHF is endemic ${ }^{7}$. Diagnostics of acute CCHF is also performed with ELISA for detection of IgG and IgM antibodies as well as CCHF virus nucleoprotein (NP) and rarely by virus isolation. Current serological assays provide reliable results and offer adequate sensitivity in clinical settings, however they all require trained personnel, are time consuming and not appropriate for POC diagnostics 7. An ideal POC test for detection of CCHF IgG would have to exhibit sensitivity and specificity similar to or greater than the current sensitivity and specificity of standard inhouse and commercial ELISA tests that ranges between $66.9-90.2 \%$ and $95.8-100.0 \%$ respectively ${ }^{5}$. Besides it would ideally give quantitative results, be easy to use, robust and offer maximum operational safety to the user.

There is a need for point-of-care diagnostic assays allowing for quick and reliable, bedside diagnostics of CCHF. Fiber-optic biosensors present a suitable alternative to existing diagnostic options for CCHF due to their small size, diagnostic accuracy and low cost. Other POC technologies, such as lateral flow have similar advantages however they do not give quantitative results and have limited multiplexing capabilities. Optic fiber biosensors are quantitative and can easily be multiplexed, a feature that would enable the design of a multiple-target POC assay. The core of optic-fiber biosensor development is the immobilization of capture affine biomolecules (eg. antigen, antibodies, nucleic acids) at the endface and the tip of an optical fiber. Target molecules then bind to the capture biomolecules and these can also bind to complementary labeled detection biomolecules. After exposure to a substrate, the marker enzyme oxidizes it and a chemiluminescent glow is produced as a side reaction that is collected 
by the optical fiber and transduced to the detector ${ }^{8}$. Previously we developed fiberoptic biosensors for sensitive detection of antibodies against Ebola virus, Rift Valley Fever virus, Dengue virus, West-Nile and Hepatitis $C^{9-13}$. The aim of this study is to develop a fiber-optic biosensor for accurate detection of antibodies against CCHF virus NP and to optimize the fiber-optic immobilization procedures so as to enhance overall signal.

\section{Materials and methods \\ Materials}

Methyl alcohol (136805) was purchased by Bio-Lab (Israel), acetic acid (45731, 99.8\% (v/v)) was purchased from Fluka, sulfuric acid (76649390, 95\% (v/v)), hydrochloric acid $(7647010,37 \%(v / v))$ and hydrogen peroxide solution $(7722841,35 \%(v / v))$ were purchased from Acros Organic (USA). 3-(Glycidoxypropyl)trimethoxysilane (GPTMS)(440167, 98\%(v/v)), sodium m-periodate (S1878), phosphate buffer saline (PBS)(P4417), sodium cyanoborohydride (71435), glycine (G7403), skim milk powder (SM)(70166), Luminol (A8511), 4-morpholinopyridine (MORP) (480657) and polyoxyethylene-sorbitan monolaurate $\left(\right.$ Tween $^{\circledR}$ 20) (P7949) were purchased from Sigma Aldrich (Israel).

\section{CCHFV-N protein expression and purification}

For expression 1-50ng of plasmid CCHFNhispET19\# (provided by Ali Mirazimi) containing the nucleocapsid gene of CCHFV strain Ibr10200 was transformed into BL21 and plated out for overnight culture on LB amp plates at $37^{\circ} \mathrm{C}$. Clones were picked and subsequently cultured overnight in $5 \mathrm{ml} \mathrm{LB}$ amp at $37^{\circ} \mathrm{C}, 50 \mathrm{ml} \mathrm{LB}$ amp culture for $24 \mathrm{~h}$ at $28^{\circ} \mathrm{C}$ after transfer of $1 \mathrm{ml}$, and $500 \mathrm{ml}$ LB amp culture after transfer of $10 \mathrm{ml}$ at $28^{\circ} \mathrm{C}$ during the following day until an OD260nm between 0.4-0.6 was reached (NanoDrop). Expression was induced with $1 \mathrm{mM}$ IPTG and the culture continued at $28^{\circ} \mathrm{C}$ overnight. A bacterial pellet was harvested by centrifugation at $4000 \mathrm{~g} / 20 \mathrm{~min}$, washed with PBS, 
resuspended im $5 \mathrm{ml}$ buffer A2, disrupted at level 3.5 (Sonifier II W-250/W-450, Branson, USA) for $30 \mathrm{sec}$ for 7 times on ice and finally centrifuged at $12.000 \mathrm{~g}, 4^{\circ} \mathrm{C}$ for $25 \mathrm{~min}$. The supernatant was transferred to equilibrated $\mathrm{Ni}$-agarose $(1.4 \mathrm{ml} \mathrm{Ni}$-agarose (Qiagen, Germany) washed twice with $10 \mathrm{ml}$ water and twice with buffer $\mathrm{A} 1$ ) and incubated for $2 \mathrm{~h}$ at $4^{\circ} \mathrm{C}$ on a shaker. After one additional centrifugation step the agarose was resuspended in $1 \mathrm{ml}$ buffer $\mathrm{A} 1$ and transferred into an empty column (Biorad, Germany). The column was then successively washed with $20 \mathrm{ml}$ buffer $B, 10 \mathrm{ml}$ buffer $\mathrm{E} 1$, and the protein was eluted with 8 fractions of $500 \mu$ l buffer E2. (Buffer A $(50 \mathrm{mM}$ Tris $(\mathrm{pH} 8,0)$, $500 \mathrm{mM} \mathrm{NaCl}, 5 \mathrm{mM} \mathrm{MgCl}, 10 \%$ Glycerin, 0,1 \% NP-40, 2mM Imidazol), buffer A1 (bufferA + 140mM ß-mercaptoethanol), buffer A2 (BufferA + 0.1mM PMSF), buffer B (buffer A1 + 28mM Imidazol), elution buffer E (20 mM Tris (pH 8.0), $100 \mathrm{mM} \mathrm{NaCl}, 5 \mathrm{mM}$ $\mathrm{MgCl}, 20 \%$ Glycerin), buffer E1 (buffer E, 2mM Imidazol), buffer E2 (buffer E, 250mM Imidazol). The protein concentration was determined by the Bradford method (BCAAssay, Pierce, UK) after confirming a pure band on an SDS page-gel.

\section{CCHF sera and antibodies}

Inactivated sera from two confirmed CCHF cases, CCHFV positive rabbit sera against $\mathrm{N}$ protein (Andersson et.al $2004 \mathrm{~J}$. Med Virol), recombinant CCHFV N protein (Andersson et.al 2004 J. Med Virol), anti-CCHFV monoclonal antibody against $\mathrm{N}$ protein and antiCCHF polyclonal rabbit antibodies were all received from the Public Health Agency of Sweden. Human IgG was detected with donkey HRP-coupled anti-human IgG antibodies. Rabbit antibodies were detected with HRP-coupled goat anti-rabbit IgG HRP (Jackson ImmunoResearch Laboratories, USA).

\section{Optical fiber immobilization}

We used SFS400/440B black Tefzel ${ }^{\circledR}$ Superguide G UV-Vis (Fiberguide Industries, Stirling, NJ, USA) optic fibers. The length of any single fiber used in the experiments was approximately $25 \mathrm{~cm}$. Tefzel $^{\circledR}$ jacket and silicon buffer were removed with a fiber 
stripping tool (Micro-Strip ${ }^{\circledR}$, from Micro-Electronics Inc., MA, USA), leaving a $0.5 \mathrm{~cm}$ nude optical fiber core tip.

Optic fibers were prepared according to the reference protocol described by Liebes et al. ${ }^{14}$. Briefly, the fibers were cleaned by sonication in $1: 1(\mathrm{v} / \mathrm{v})$ methanol/ $97 \% \mathrm{HCl}$ solution for $10 \mathrm{~min}$ at $90^{\circ} \mathrm{C}$ and treated with piranha solution $\left(7: 3[\mathrm{v} / \mathrm{v}] \mathrm{H}_{2} \mathrm{SO}_{4} / \mathrm{H}_{2} \mathrm{O}_{2}\right)$ to produce surface hydroxyl groups, rinsed with nanopure water and dried with nitrogen gas. Fiber surfaces were then silanized with (3-glycidoxypropyl)trimethoxysilane for 60 $\min$ at $90^{\circ} \mathrm{C}$. Fibers were treated with $11.6 \mathrm{mM}$ hydrochloric acid for $60 \mathrm{~min}$ (formation of vicinal diols) and $100 \mathrm{mM}$ sodium m-periodate dissolved in $10 \%$ (v/v) acetic acid for $60 \mathrm{~min}$ at room temperature (oxidation to aldehyde). Fibers were then rinsed with deionized water and incubated with $1 \mathrm{ml}$ of $0.43 \mu \mathrm{g} / \mathrm{ml} \mathrm{HRP} \mathrm{(for} \mathrm{assay} \mathrm{optimization)} \mathrm{or}$ CCHFV NP (for assay validation) overnight at 4ㅇ.C. Un-reacted aldehyde groups were blocked using $1 \mathrm{M}$ glycine for $30 \mathrm{~min}$ at RT and the unsaturated amines were stabilized by a Schiff base with $0.3 \mathrm{M}$ sodium cyanoborohydride for $60 \mathrm{~min}$ at RT.

\section{Fiber-optic chemiluminescent and Colorimetric immunoassay}

Instrument set-up for chemiluminescence measurements was performed as previously described $[22,23]$. A Hamamatsu HC135-01 Photo Multiplier Tube (PMT) Sensor Module was used for chemiluminescence measurements in a light-tight box. The far end of the fiber was held by a fiber holder (FPH-DJ, Newport) and placed into an adjustable singlefiber mount (77837, Oriel). Real-time data acquisition was performed using LabView (version 3.1, National Instruments Corporation). Chemiluminiscence detection was performed with the Immuno-star HRP chemiluminescent kit (170-5040, Bio-Rad Laboratories, France). Chemiluminescence readings were integrated for $1 \mathrm{~s}$, measuring a mean value of photon counts during $15 \mathrm{~s}$. Results are presented as the mean and standard deviation of relative light units (RLU). Colorimetric detection was performed using $100 \mu \mathrm{l}$ 3,3,5,5-tetramethylbenzidine (TMB) (T0440, Sigma Aldrich, Israel) and 50 $\mu \mathrm{l}$ of $2 \mathrm{~N} \mathrm{H}_{2} \mathrm{SO}_{4}$ afterwards in each well. Optical density readings at 450 were determined with a Labsystems Multiscan RC ELISA reader. 


\section{Protocol optimization}

The initial immobilization protocol (Protocol 1) ${ }^{14}$ was optimized in order to achieve maximum output chemiluminescence signal levels. For protocol optimization we immobilized $200 \mathrm{U} / \mathrm{ml} \mathrm{HRP}$ on the fiber optic. Optimization steps are shown in Table 1. Steps with the highest chemiluminescence output comprise the optimized protocol (Protocol 2), which we used for the optic-fibre immobilization with CCHF virus NP.

We also evaluated the effect of two different HRP substrate compositions. We compared the output levels of the Immuno-star-HRPTM substrate (Bio-Rad), that includes 1:1 luminol/enhancer and stable peroxide buffer, and a substrate described by Vdovdenko et al. ${ }^{15}$ that is based on the addition of two enhancers: SPTZ (sodium salt of 3-(10'-phenothiazinyl)propane-1-sulfonate) and MORP (4-morpholinopyridine). A total of $240 \mu$ l substrate was added to each well.

\section{Fiber-optic immunoassay for detection of CCHF antibodies}

Assay's sensitivity was evaluated with a $10^{2}$ to $10^{6}$ dilution range of Polyclonal Rabbit anti-CCHF virus antibodies. Briefly, $200 \mu$ diluted antibodies were added per well (five sets of triplicates) and incubated for $60 \mathrm{~min}$.

Sensitivity of the assay was further evaluated with two confirmed samples from two CCHF patients from Turkey. The samples were collected for routine diagnostic purposes in Turkey and development of diagnostic tools and their collection was approved by the governing ethical committee (Turkish Public Health Institution). Serum samples were chosen based on their initial serology results: high-level IgG for patient 1 (CDC ELISA, OD: 2) and low-level IgG for patient 2 (OD: 0,4).

Optic fibers were incubated with $200 \mu$ l diluted serum (dilutions from $10^{3}$ to $10^{6}$ ) for $60 \mathrm{~min}$ (three sets of triplicates). Unmodified fibers were used to check the level of background signal. Optic fiber tips were washed four times with PBST-BSA for a onetime $10 \mathrm{~min}$, followed by a three time $3 \mathrm{~min}$ protocol. Fibers were then dipped into 
$200 \mu$ l donkey anti-human IgG peroxidase-labeled antibodies (1/500) for $60 \mathrm{mi}$ and washed with PBS-Tween before chemiluminiscence detection as described above.

\section{CCHF IgG ELISA}

Fiber-optic immunoassay for detection of CCHF virus antibodies performance was compared to the performance of CCHF IgG ELISA. MaxiSorp 96-well microtiter plates (Nunc) were coated with $100 \mu \mathrm{l} /$ well of CCHF virus NP. Plates were placed overnight at 4 으. Plates were then washed three times with $100 \mu$ l of PBS each. Each well was blocked by $150 \mu \mathrm{l} /$ well of blocking solution (1M glycine (w/v) in PBS buffer, pH 7.2) for $1 \mathrm{~h}$ at $37^{\circ} \mathrm{C}$. Plates were washed three times with $100 \mu \mathrm{l} 0.1 \%$ PBST containing $5 \%(\mathrm{w} / \mathrm{v})$ skimmed milk (washing step). Serial dilutions $\left(10^{-2}-10^{-6}\right)$ of anti-CCHF antibodies $\left(100 \mu \mathrm{L} /\right.$ well) were added in triplicates and incubated for $1 \mathrm{~h}$ at $37^{\circ} \mathrm{C}$ followed by a washing step. Goat anti-mouse IgG peroxidase-labeled antibodies (100 $\mu \mathrm{l} /$ well) $\left(10^{3}\right)$ were added and incubated for $1 \mathrm{~h}$ at $37^{\circ} \mathrm{C}$, followed by a washing step. Two different substrates were used. For colorimetric ELISA, we added 3,3',5,5' tetramethylbenzidine (TMB) $(100 \mu \mathrm{l} /$ well) and incubated at room temperature for $30 \mathrm{~min}$ in the dark. The reaction was stopped with $2 \mathrm{~N} \mathrm{H}_{2} \mathrm{SO}_{4}(50 \mu \mathrm{l} /$ well). Optical density reads at $450 \mathrm{~nm}$ $\left(O D_{450}\right)$ were determined with the Labsystems Multiscan RC ELISA reader. Results are presented as the mean and standard deviation of $\mathrm{OD}_{450}$. 


\section{Results and Discussion}

The aim of this study was to develop and optimize a fiber optic biosensor for detection of CCHF virus antibodies. As a starting point we used a previously described immobilization protocol (Protocol 1) ${ }^{14}$ and optimized each step in order to maximize the chemiluminescence output. In the cleaning step we tested the effects of sonication and duration of methanol washing. We showed that sonication significantly increased the biosensor end point signal output (RLU 6857 vs. 1114 without sonication) and that methanol washing for $20 \mathrm{~min}$ was the most effective. Next we wanted to assess the efficacy of optical fiber activation (production of surface hydroxyl groups) using different activating solutions. Namely, we wanted to replace the piranha solution with a safer alternative as it is highly toxic and dangerous, requires special handling and disposal measures. However, our results show that the piranha solution was by far the most effective activator, with the biosensor output of $16669 \mathrm{RLU}$. Neither $\mathrm{HCL}, \mathrm{H}_{2} \mathrm{SO}_{4}$, $\mathrm{CH}_{3} \mathrm{COOH}$ or $\mathrm{H}_{3} \mathrm{PO}_{4}$ had comparable results (RLU: 3598, 9625, 1991, 5681, respectively). Piranha solution was therefore used in the optimized protocol (Protocol 2). Next step was the optimization of the silanization process. We tested 3 different temperatures $\left(30^{\circ} \mathrm{C}, 60^{\circ} \mathrm{C}\right.$ and $90^{\circ} \mathrm{C}$ ) and 3 different durations (30 min, $60 \mathrm{~min}, 90 \mathrm{~min}$ ) of silanization. We obtained the highest biosensor output at $60^{\circ} \mathrm{C}$ for $60 \mathrm{~min}(8660 \mathrm{RLU})$. In the last step we optimized the temperature and duration of treatment with sodium m-peroxidate. The highest biosensor output was achieved at $25^{\circ} \mathrm{C}$ for $90 \mathrm{~min}$ (20594 RLU). The results of the protocol optimization are shown in Table 1.

Next, we compared protocols 1 and 2 for their overall performance in the immunoassay, and as seen in Figure 1, the sensitivity of protocol 2 is 100 -fold higher (limit of detection for protocol 1 is antibody dilution $10^{-4}$ and for protocol 2 is $10^{-6}$ ). The results show that optimization steps had great influence on the overall efficacy of the immunoassay. Protocol 2 was therefore used for validation of the fiber-optic biosensor using patient sera. 
We also compared two different substrate formulations with respect to the overall biosensor output. We wanted to assess if enhancers (SPTZ or MORP) added to the luminol/peroxide substrate, would enhance the biosensor's output, and indeed, as seen in figure 2, the addition of the two enhancers did increase the biosensor's output by roughly 10-fold. An additional advantage in using SPTZ/MORP enhancers is that they provide a more durable light signal that increases the biosensor's sensitivity ${ }^{16}$.

In the last step we evaluated the sensitivity of the developed fiber-optic biosensor for the detection of CCHF IgG antibodies in human sera. We tested the assay with both patients' sera. Fiber-optic biosensor detection was more sensitive than ELISAs. The lowest limit of detection of Patient 1 serum was 10-fold greater compared to ELISA, down to titer $1: 1,000,000$. The assay was also able to detect the low positive serum sample of Patient 2 down to titer 1:5,000 (Table 2).

Our results show that our fiber-optic biosensor is a suitable alternative for ELISA, for the detection of CCHF virus IgG antibodies. The assay enables rapid and sensitive detection of CCHF antibodies and can be manufactured as a semi-disposable, point-of-care device. The technology also enables us to modify the device to enable detection of other biomolecules (e.g. CCHF RNA). Another advantage of the proposed biosensor is that it does not require trained personnel or expensive equipment for its operation. Today's diagnostic assays lack these features and are therefore available only at select diagnostic centers. However, the endemic areas of CCHF are mainly rural areas with limited access to these high-end diagnostic services. High pathogenicity of CCHF and the risk of human-to-human transmissions, especially in hospital settings, warrant the development of point-of-care devices that would enable quick, safe and reliable diagnostics of CCHF. The main advantage of the fiber optic biosensor is that it provides sensitive results and can be designed as a point-of-care device at a cost comparable to current standard ELISA assays. The assay could serve as a rapid, primary diagnostic tool for bedside CCHF diagnostics in endemic areas where extensive diagnostic equipment and trained personnel are not available. The fiber-optic biosensor could provide the 
necessary solution, however further studies are needed to determine the actual clinical sensitivity and specificity of the assay on a larger scale.

\section{Acknowledgements}

This project was funded by the CCH Fever Network (Collaborative Project) supported by the European Commission under the Health Cooperation Work Program of the 7th Framework Program (Grant agreement no. 260427). We thank Doris Heidenreich for technical assistance and Gulay Korukluoğlu for the human serum samples.

\section{References}

(1) Tarantola, A.; Ergonul, O.; Tattevin, P.; Ergonul, O.; Whitehouse, C. A. Springer: Netherlands, 2006; pp. 281-294.

(2) Pshenichnaya, N. Y.; Nenadskaya, S. A. Int. J. Infect. Dis. 2015, 33C, 120-122.

(3) Papa, A.; Mirazimi, A.; Köksal, I.; Estrada-Pena, A.; Feldmann, H. J. Clin. Virol. 2014.

(4) Conger, N. G.; Paolino, K. M.; Osborn, E. C.; Rusnak, J. M.; Günther, S.; Pool, J.; Rollin, P. E.; Allan, P. F.; Schmidt-Chanasit, J.; Rieger, T.; Kortepeter, M. G. Emerging Infect. Dis. 2015, 21, 23-31.

(5) Vanhomwegen, J.; Alves, M. J.; Zupanc, T. A.; Bino, S.; Chinikar, S.; Karlberg, H.; Korukluoğlu, G.; Korva, M.; Mardani, M.; Mirazimi, A.; Mousavi, M.; Papa, A.; Saksida, A.; Sharifi-Mood, B.; Sidira, P.; Tsergouli, K.; Wölfel, R.; Zeller, H.; Dubois, P. Emerging Infect. Dis. 2012, 18, 1958-65.

(6) Escadafal, C.; Olschlager, S.; Avsic-Zupanc, T.; Papa, A.; Vanhomwegen, J.; Wolfel, R.; Mirazimi, A.; Teichmann, A.; Donoso-Mantke, O.; Niedrig, M. PLoS neglected tropical diseases 6, e1706.

(7) Bente, D. A.; Forrester, N. L.; Watts, D. M.; McAuley, A. J.; Whitehouse, C. A.; Bray, M. Antiviral Res. 2013, 100, 159-89.

(8) Collings, A.; Caruso, F. Reports on Progress in Physics 60, 1397-1445.

(9) Sobarzo, A.; Paweska, J.; Herrmann, S.; Amir, T.; Marks, R.; Lobel, L. Journal of Virological Methods 146, 327-334.

(10) Konry, T.; Novoa, A.; Shemer-Avni, Y.; Hanuka, N.; Cosnier, S.; Lepellec, A.; Marks, R. S. Anal. Chem. 2005, 77, 1771-9.

(11) Atias, D.; Liebes, Y.; Chalifa-Caspi, V.; Bremand, L.; Lobel, L.; Marks, R.; Dussart, P. Sensors and Actuators, B: Chemical 1899, 140, 206-215. 
(12) Herrmann, S.; Leshem, B.; Landes, S.; Rager-Zisman, B.; Marks, R. S. Talanta 2005, 66, 6-14.

(13) Petrosova, A.; Konry, T.; Cosnier, S.; Trakht, I.; Lutwama, J.; Rwaguma, E.; Chepurnov, A.; Mühlberger, E.; Lobel, L.; Marks, R. Sensors and Actuators B: Chemical 2007, 122, 578586.

(14) Liebes, Y.; Amir, L.; Marks, R.; Banai, M. Talanta 1901, 80, 338-345.

(15) Vdovenko, M.; Ciana, L.; Sakharov, I. Analytical Biochemistry 392, 54-58.

(16) Vdovenko, M.; Ciana, L.; Sakharov, I. Biotechnology Journal 5, 886-890. 
Table 1: Optimization steps for optical fiber immobilization (in bold are the parameters that define the optimized protocol 2)

\begin{tabular}{|c|c|c|c|}
\hline \multirow{2}{*}{$\begin{array}{l}\text { Step } \\
\text { Cleaning }\end{array}$} & \multicolumn{2}{|c|}{ Optimization } & \multirow{2}{*}{$\begin{array}{l}\text { Biosensor output } \\
{[\text { RLU] }} \\
6857(39.72)\end{array}$} \\
\hline & Sonication & With & \\
\hline & & Without & 1114 (15.92) \\
\hline & Methanol & $10 \mathrm{~min}$ & $4710.17(24.78)$ \\
\hline & & $20 \mathrm{~min}$ & $13402.88(16.86)$ \\
\hline & & $30 \mathrm{~min}$ & $13141.38(18.03)$ \\
\hline \multirow[t]{5}{*}{ Activation } & & $\mathrm{HCL}$ & $3598(7.6)$ \\
\hline & & Piranha & $16669(31.8)$ \\
\hline & & $\mathrm{H}_{2} \mathrm{SO}_{4}$ & $9625(26.2)$ \\
\hline & & $\mathrm{CH}_{3} \mathrm{COOH}$ & 1991 (26.4) \\
\hline & & $\mathrm{H}_{3} \mathrm{PO}_{4}$ & $5681(16.34)$ \\
\hline \multirow[t]{9}{*}{ Silanization } & $30 \mathrm{~min}$ & $30 \div \mathrm{C}$ & $1428(32)$ \\
\hline & & $60 \circ \mathrm{C}$ & $2760(50)$ \\
\hline & & $90 \div \mathrm{C}$ & $1644(33)$ \\
\hline & $60 \mathrm{~min}$ & $30 \div \mathrm{C}$ & 1864 (37) \\
\hline & & $60 \div \mathrm{C}$ & 8660 (17) \\
\hline & & $90 \circ \mathrm{C}$ & $2941(46)$ \\
\hline & $90 \mathrm{~min}$ & $30 \circ \mathrm{C}$ & $3797(28)$ \\
\hline & & $60 \div \mathrm{C}$ & $4198(40)$ \\
\hline & & $90 \circ \mathrm{C}$ & $1204(3)$ \\
\hline \multirow{9}{*}{$\begin{array}{l}\text { Sodium m- } \\
\text { periodate }\end{array}$} & $30 \mathrm{~min}$ & $25 \div \mathrm{C}$ & $1576(31.5)$ \\
\hline & & $30 \div \mathrm{C}$ & 1870 (35.9) \\
\hline & & $60 \div \mathrm{C}$ & 1415 (16.4) \\
\hline & $60 \mathrm{~min}$ & $25 \circ \mathrm{C}$ & 9086 (31.5) \\
\hline & & $30 \circ \mathrm{C}$ & 3357 (15.4) \\
\hline & & $60 \div \mathrm{C}$ & 3465 (36.4) \\
\hline & $90 \mathrm{~min}$ & $25 \circ C$ & 20594 (18.9) \\
\hline & & $30 \circ \mathrm{C}$ & 7884 (33.4) \\
\hline & & $60 \div \mathrm{C}$ & 3626 (26.1) \\
\hline
\end{tabular}


Table 2: Immunoassay results

\begin{tabular}{llcc} 
Sample & Dilution & $\begin{array}{c}\text { Fiber optic } \\
\text { biosensor }\end{array}$ & ELISA \\
\hline Patient 1 & $1: 5000$ & + & + \\
& $1: 10000$ & + & + \\
& $1: 20000$ & + & + \\
$1: 50000$ & + & + \\
& $1: 100000$ & + & + \\
& $1: 250000$ & + & - \\
& $1: 500000$ & + & - \\
& $1: 750000$ & + & - \\
& $1: 1000000$ & + & - \\
\hline Patient 2 & $1: 1000$ & + & $\mathrm{ND}$ \\
& $1: 5000$ & + & $\mathrm{ND}$ \\
& $1: 10000$ & - & $\mathrm{ND}$ \\
\hline No serum control & & - & - \\
Human serum control & & - & - \\
Rabbit serum control & & - & - \\
Positive control & & + & + \\
No primary antibody & & - & - \\
No secondary antibody & & - & - \\
\hline
\end{tabular}

ND not determined 
1

2

3

4

5

6

7

8

9

10

11

12

13

14

15

16

17

18

19

20

21

22

23

24

25

26

27

28

29

30

31

32

33

34

35

36

37

38

39

40

41

42

43

44

45

46

47

48

49

50

51

52

53

54

55

56

57

58

59

60

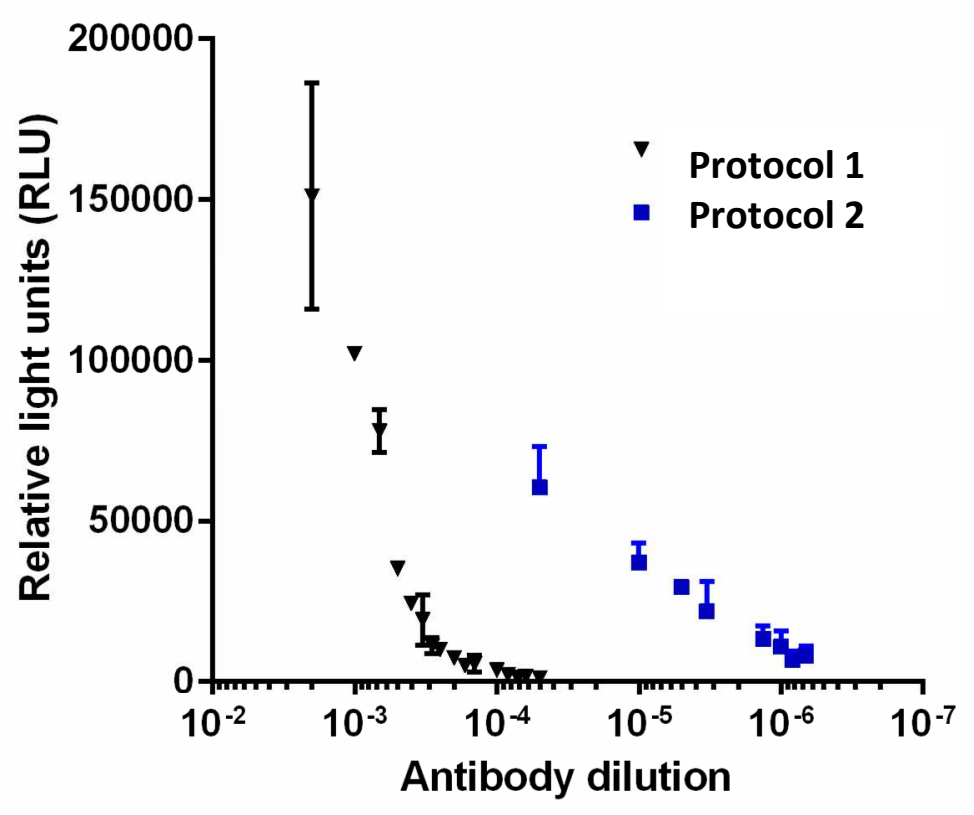

Figure 1: Immunoassay results for the comparison of immobilization protocols 1 and 2. 


\section{Substrate}

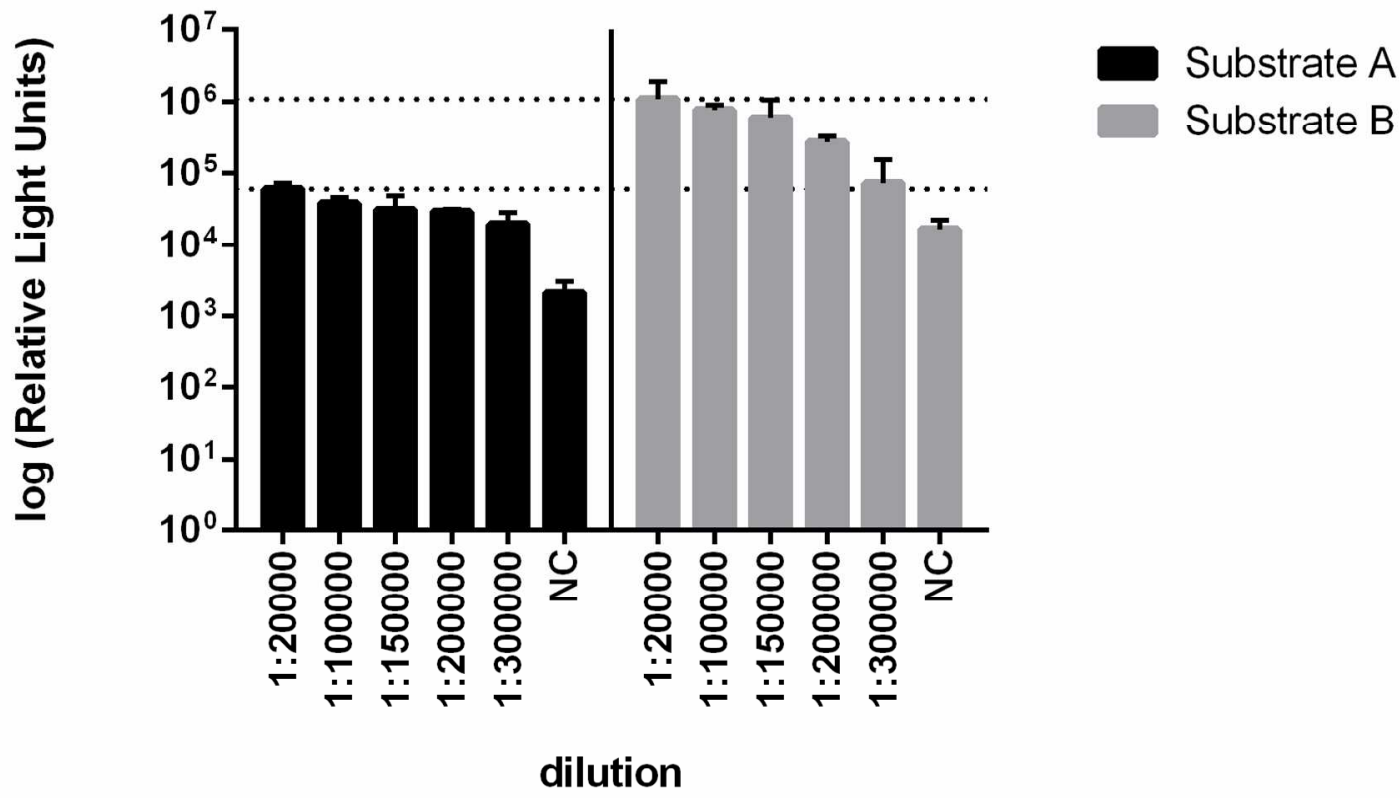

Figure 2: Immunoassay results for the comparison of two substrate formulations. Substrate A is a commercial luminol/peroxide formulation, substrate $B$ includes two additional enhancers, SPTZ and MORP. NC= negative control. 
1

2

3

4

5

6

7

8

9

10

11

12

13

14

15

16

17

18

19

20

21

22

23

24

25

26

27

28

29

30

31

32

33

34

35

36

37

38

39

40

41

42

43

44

45

46

47

48

49

50

51

52

53

54

55

56

57

58

59

60

\section{For TOC only}

\begin{tabular}{|ccc|}
\hline \multicolumn{3}{c|}{ Crimean-Congo hemorrhagic fever IgG } \\
dilution & Fiber optic biosensor & IgG ELISA \\
\hline $1: 500$ & + & + \\
$1: 10000$ & + & + \\
$1: 20000$ & + & + \\
$1: 50000$ & + & + \\
$1: 100000$ & + & \\
$1: 250000$ & + & \\
$1: 500000$ & + & \\
$1: 750000$ & + & \\
$1: 1000000$ & + & \\
\hline
\end{tabular}

